\title{
Speculations on the Origin and Evolution of the Genus Leishmania
}

\author{
Hooman Momen ${ }^{+}$, Elisa Cupolillo* \\ Departamento de Bioquímica e Biologia Molecular *Departamento de Imunologia, Instituto Oswaldo Cruz, \\ Av. Brasil 4365, 21045-900 Rio de Janeiro, RJ, Brasil
}

Recently two hypotheses have been proposed for the evolution of Leishmania involving respectively a Neotropical or Paleartic origin for the species. Here an alternative proposal on the phylogeny of Leishmania based on the major divisions within the genus is presented. In this hypothesis a Neotropic origin is retained for $\mathrm{L}$. (Viannia) and Paraleishmania, a recently desribed section within the genus Leishmania, while an African origin is proposed for L. (Leishmania) and possibly Sauroleishmania. The current distribution of Leishmania in the Neotropics is explained as the product of multiple introductions of Leishmania parasites into the New World. Problems with organismal identity in Sauroleishmania and the use of molecular sequence data in inferring phylogenies are also discussed.

Key words: Euleishmania - Paraleishmania - Leishmania evolution - biogeographical associations - phylogeny

Recent molecular sequence studies have revived interest on the origin and evolution of the genus Leishmania. Noyes (1998) has renewed the hypothesis of a Neotropical origin for the genus using arguments mainly based on the published gene sequence phylogenies. This hypothesis has been contested by Kerr (2000) who instead proposed a Paleartic origin for Leishmania and suggested that the genus was only introduced into the Neotropics during the Pliocene after the formation of the Panamanian land bridge about 3 million years ago.

\section{MAJOR DIVISIONS IN THE GENUS LEISHMANIA}

More recently Cupolillo et al. (2000) have proposed the separation of the genus Leishmania into two divisions, Euleishmania and Paraleishmania, called sections by analogy with a similar division in Trypanosoma. The Euleishmania is comprised of the subgenera Leishmania and Viannia as described by Lainson and Shaw (1987) and the Paraleishmania, which consists of $L$. hertigi, L.deanei, L. colombiensis, L. equatorensis, $L$. herreri as well as strains of Endotrypanum. These two sections can be clearly distinguished by a variety of molecular techniques (Cupolillo et al. 2000).

The Paraleishmania can also be further sub-divided by the molecular criteria, one group formed

\footnotetext{
${ }^{+}$Corresponding author. Fax: 55-21-290.3495. E-mail: hmomen@ioc.fiocruz.br Received 13 April 2000 Accepted 15 May 2000
}

by parasites of histricomorph rodents (porcupines) namely $L$. hertigi and $L$. deanei and the other group formed by the remaining species which are principally parasites of sloths. Strains of Endotrypanum currently maintained in laboratory collections form a polyphyletic group within the Paraleishmania. The strains cannot currently be shown to infect erythrocytes nor demonstrate the characteristic trypomastigote or epimastigote forms of the genus. They are probably better considered as species of Paraleishmania from which they are currently indistinguishable and the name Endotrypanum reserved for the true intraerythrocytic parasite of sloths when this parasite is eventually re-isolated and can demonstrate features associated with the description of the genus.

In the Table the major groupings presently recognised in the genus Leishmania are listed. An examination of this Table would indicate an Old World origin for Sauroleishmania and a New World origin for Paraleishmania and L. (Viannia) as the most parsimonious explanations (without involving reverse migrations between or extinctions within either the Old World or New World) for the evolution of these groups. As the genus Leishmania is thought to be monophyletic (Thomaz-Soccol et al. 1993, Croan et al. 1997), the origin of the L. (Leishmania) subgenus which has a worldwide distribution appears then to be the key for understanding the phylogeny of the genus.

\section{AN AFRICAN ORIGIN FOR L. (LEISHMANIA)}

L. (Leishmania) can be divided into a number of species complexes. In the Old World the principal species complexes are $L$. donovani/L. infantum, L. tropica, L. major and L. aethiopica. There are 
TABLE

Distribution of principal Leishmania groups

\begin{tabular}{|c|c|c|c|}
\hline Genus/sub-genus/species & Section & Vector & Distribution \\
\hline Sauroleishmania & $?$ & Sergentomyia & Old World \\
\hline L. (Leishmania) & Euleishmania & Phlebotomus/Lutzomyia & Worldwide \\
\hline L. (Viannia) & Euleishmania & Lutzomyia & New World \\
\hline L. hertigi, L. deanei ${ }^{a}$ & Paraleishmania & Lutzomyia & New World \\
\hline L. colombiensis, L. equatorensis, L. herreri ${ }^{a}$ & Paraleishmania & Lutzomyia & New World \\
\hline
\end{tabular}

$a$ : includes laboratory strains currently classified as Endotrypanum.

strong indications that all of these complexes have an African origin.

L. aethiopica occurs only in the Ethiopian and Kenyan highlands, its reservoir is the rock hyrax and its vector is $P$. (Larroussius). Due to its restricted geographical range it seems reasonable to assume an African origin for this species as well as for other L. (Leishmania) - hyrax systems that occur in Africa such as that found in Namibia (Lanotte et al. 1986).

Four host parasite-ecology systems have been described for $L$. major based on the principal vertebrate hosts namely Psammomys, Meriones, Rhombomys and Arvicanthis and the sand fly vectors of the genus Phlebotomus. Of these the Arvicanthis/Phlebotomus has been assumed to be the most primitive system and an evolutionary process originating with Arvicanthis transferring to Meriones and then to the other hosts has been postulated (Ashford 1986). The distribution of Arvicanthis is restricted to sub-Saharan Africa, therefore an African origin for this species is possible.

A number of studies have shown that the $L$. donovani and $L$. infantum complexes are monophyletic (Mauricio et al. 1999) and a common origin in East Africa has been postulated for these visceralizing species based on a cladistic analysis of isoenzymes (Moreno et al. 1986 ). An African origin for the visceralizing species of the $L$. donovani complex has also been argued by Ashford et al. (1992). They have suggested an ancient cluster derived from an ancestral root stock in the Sudan from which all other forms of the complex have derived. A primitive host parasite-ecology system in Arvicanthis has also been proposed for this species (Ashford 1986).

Traditionally the distribution of $L$. tropica was not associated with Africa (Lysenko 1971) however L. killicki a member of the species complex is found in this continent (Rioux et al. 1986). More recently foci of $L$. tropica have been identified in Kenya (Mebratu et al. 1992) and L. tropica is not known to be zoonotic anywhere else but Africa in its distribution (Sang et al. 1994). Man is believed to have originated in Africa and it is reasonable to consider that anthroponotic parasites such as members of the L. tropica and (L. donovani) complex which have evolved with him may also have originated there.

We therefore propose that the Old World species of Leishmania evolved in Africa probably from an ancestral origin in East Africa. In the New World L. (Leishmania) contains the L. mexicana complex and $L$. chagasi. Many authors now consider $L$. chagasi to have originated from $L$. infantum strains brought to the New World in historical times (KillickKendrick et al. 1980, Moreno et al. 1986, Momen et al. 1987, Thomaz-Soccol et al. 1993, Mauricio et al. 1999). This parasite therefore also seems to be derived from the same African root stock as $L$. infantum.

L. mexicana shares many characteristics with L. major (Lainson \& Shaw 1987). In particular $L$. mexicana in North America (Texas) has many similarities to L. major in Asia (Kerr 2000). It has been postulated that L. (Leishmania) could have evolved in the Paleartic and dispersed to the Neartic together with its rodent reservoirs during the Eocene at which time the Bering land bridge was intact (Thomaz-Soccol et al. 1993, Kerr 2000). L. (Leishmania) could then have entered the Neotropics either by island hopping (Cox \& Moore 2000) as species of the L. mexicana complex are found presently on a number of Carribean islands, or after the formation of the Panamanian land bridge during the Pliocene. In South America climatic and ecological factors could have favoured further speciation giving raise to other members of the the $L$. mexicana complex such as $L$. venezuelensis, $L$. amazonensis, L. garnhami, L. foratinni and by adaptation to guinea pigs the related species $L$. enrietti.

The alternative hypothesis of a Neotropical origin for L. (Leishmania) and subsequent migration to the Neartic and Paleartic raises several problems as outlined by Noyes (1998) and Kerr (2000). These problems include inconsistence with current classifications of sand flies, the necessity for multiple adaptations to murine rodents in the Neotropic, Neartic and Paleartic or reverse migration of the parasite across the Behring straits. 


\section{CAN WE TRUST THE TREES WE HAVE}

If L. (Leishmania) arose in Africa, how can we reconcile this with the origin of the other major clades within the genus and the molecular phylogenetic trees. Molecular sequence data have been the basis for much of the advances in modern phylogenetics revealing new relationships between organisms that were overlooked by more traditional methods. However the vast increase in molecular data has also brought to surface increased concern about the resolution of molecular phylogenies.

These criticisms can be classified into at least three kinds. The first kind of criticism can be considered methodological and include problems such as long branch attractions (Felsenstein 1978) mutational saturation, and among site rate variation (Yang 1996). Phillipe (1998) has reviewed the numerous phylogenies that have been published for the kinetoplastids and discusses possible explanations for the observed discrepancies. He has also demonstrated the lack of molecular clock behaviour for all genes studied in the kinetoplastids. Stothard (2000) has pointed out the problem of paralogous genes producing false phylogenies when tandem repeated genes present in the genome are used to construct trees.

The second kind of criticism is directed at the conceptual basis of molecular phylogeny and can be considered epistemological. It is concerned with the idea that gene phylogeny cannot be equated with organismal phylogeny and that organisms are more than just the sum of their genes (Doolitle 1999). The third kind of criticism has arisen from the surge in genome sequence information which has demonstrated numerous cases of horizontal gene transfer (HGT) between organisms. For example 234 examples of HGT have been detected since the divergence of Escherichia coli and Salmonella comprising about $17 \%$ of the genome (Lawrence \& Ochman 1998). Although most examples are from prokaryotes, eukaryotes have also been shown to possess the same capacity and similar mechanism for HGT (Cruz \& Davies 2000). These authors have suggested that HGT can provide an alternative explanation for macroevolution in certain situations and thus questioning in these cases phylogenies based on fixed mutations.

These concerns have led Doolittle (1999) to conclude that the relationship between genes "is thus not a fair (at least complete) depiction of the actual evolutionary history of any lineage of real organisms".

\section{SAUROLEISHMANIA}

Bearing Doolittle's warning in mind we can now return to our analysis of the major Leishmania groups. The position of the reptile Leishmania has been a point of contention. The position of these parasites at the crown of the molecular trees (Croan et al. 1997) indicating a recent origin and monophyly with L. (Leishmania) is at odds with the opinion of most field parasitologists who consider the parasites belong to a separate genus Sauroleishmania based on a variety of extrinsic and intrinsic characters (Killick-Kendrick et al. 1986).

In addition to the general concerns of molecular phylogenetics, the trees involving Sauroleishmania have particular problems involving organismal identity. Most Sauroleishmania isolates have been maintained as cryostabilates and/or in vitro culture for several decades with all the implications for gene selection and confusion over identity. In addition the isolate of L. adleri used in several studies is indistinguishable from a reference strain of L. major (Cupolillo, unpublished results). A further example of possible misidentification in reptile Leishmania is given by Telford (1985). For these reasons the Sauroleishmania were not included in the sections proposed by Cupolillo et al. (2000).

Therefore molecular trees involving Sauroleishmania should be treated with particular caution until many fresh isolates from a variety of reptile hosts become available. In view of the current lack of field parasitologists working on reptile Leishmania we would agree with Noyes et al. (1998) that if these parasites were placed in a separate genus there is a risk that they will be ignored as an academic curiosity.

The molecular tree of Croan et al. (1997) could indicate that the Sauroleishmania diverged from L. (Leishmania) in the Paleartic prior to the migration of the latter through the Behring straits. However alternative explanations for the origin of Sauroleishmania which are not supported by the current molecular phylogeny have been proposed. These generally place the Sauroleishmania at the root of the tree due to development in the vector similar to that of primitive insect trypanosomatids and the ancient origins of lizards (Lainson \& Shaw 1987). Sauroleishmania have been isolated from several species of lizards in East Africa so that $L$. (Leishmania) could have diverged from reptile parasites in this region under this alternative hypothesis. In this sense the report by Okot-Kotber et al. (1989) of the isolation of L. major from a lizard in this area is of interest.

\section{L. (VIANNIA) AND PARALEISHMANIA}

Kerr (2000) has considered that L. (Viannia) originated through rapid speciation, greatly favoured by climatic and ecological factors, after the introduction of L. (Leishmania) in the Neotropic. However the large genetic distance 
between the two subgenera and the great genetic diversity within L. (Viannia) (Cupolillo et al. 1995) together with the preferential association of the latter subgenus with indigenous mammals of the New World favours a more ancient origin. We prefer the hypothesis that with the separation of Gondwanda in the Mesozoic, Euleishmania evolved into $L$. (Leishmania) in Africa and L. (Viannia) in South America as previously proposed by Saf 'janova (1986) and Thomaz-Soccol et al. (1993).

Further studies are required to understand the evolution of Paraleishmania. The wide difference between the molecular properties of Euleishmania and consequently L. (Viannia) on the one hand and Paraleishmania on the other (Cupolillo et al. 2000) would also favour an ancient divergence between these groups. However some similarities between Paraleishmania and L. (Viannia) have also been noted such as cross-hybridization with kDNA (Pacheco et al. 1990) as well as absence of GP46/ M2 genes in Paraleishmania and L. (Viannia) and their presence in L. (Leishmania) and Sauroleishmania (McMahon-Pratt et al. 1992, Cupolillo, unpublished results). We can speculate that the separation of the genus into two sections occurred either before the separation of Gondwanda or the distinct Paraleishmania of porcupines may suggest an origin in these animals as porcupines are host to no other kind of Leishmania.

\section{MULTIPLE ORIGINS OF LEISHMANIA IN THE NEOTROPICS}

The present hypothesis on the origin of Leishmania better reflects the molecular systematic data available and in particular the large differences between the Paraleishmania and the Euleishmania subgenera Viannia and Leishmania. It is important to compare phylogenies based on several independent genes that display different evolutionary constraints as suggested by Phillipe (1998). He suggests the elongation factor $\left(\mathrm{EF}-1^{\mathrm{a}}\right)$, heat shock protein (HSP70) and glyceraldehyde dehydrogenase (GAPDH) genes, all single copy protein coding genes, as suitable candidates for the study of the molecular systematics of kinetoplastids.

Until further data with large sampling becomes available we would propose an African origin for $L$. (Leishmania) associated with Sauroleishmania and four separate events or introductions of the genus Leishmania into the Neotropics (Figure). L. (Viannia)

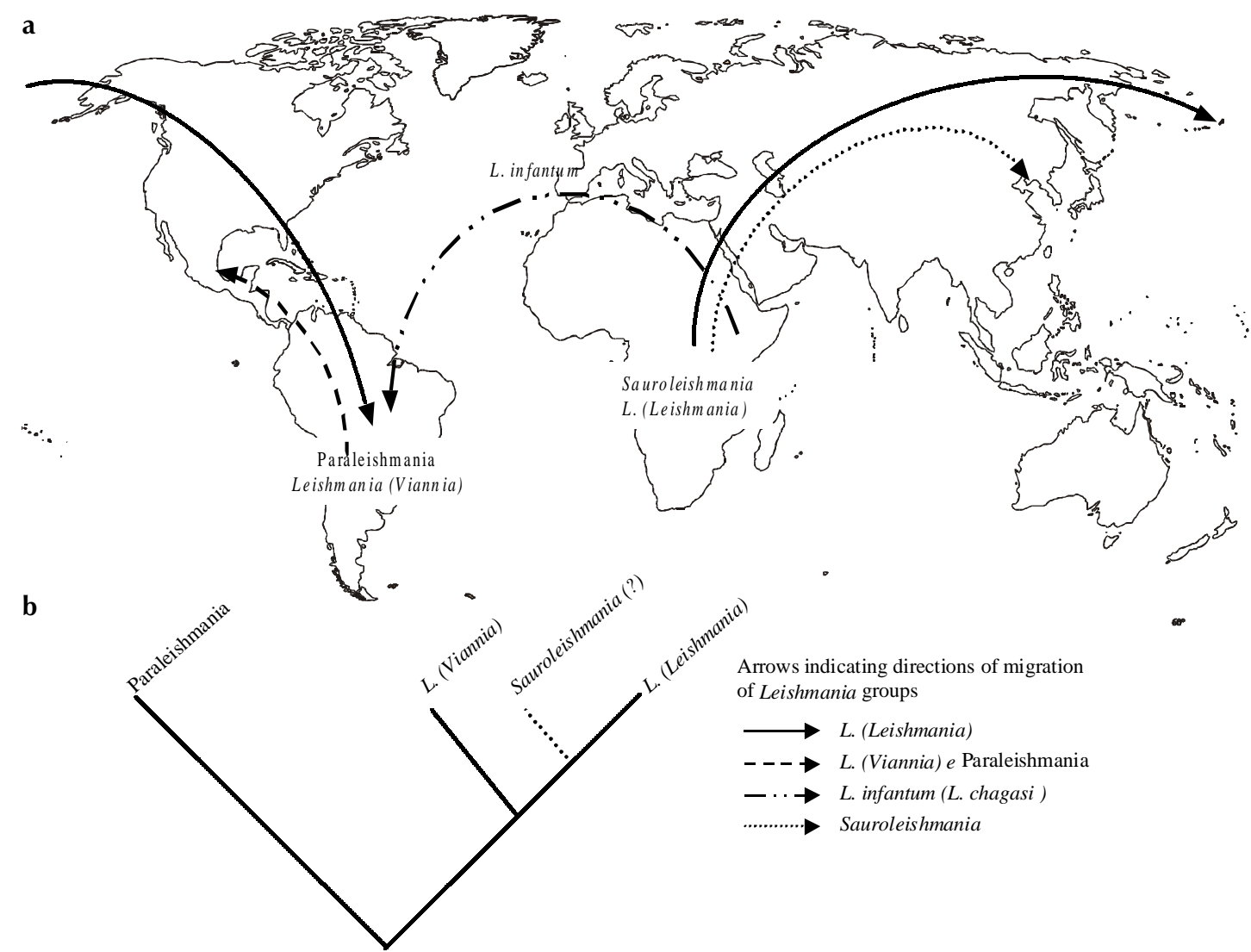

a: map indicating possible migration routes of major Leishmania groups; b: phylogram showing relationships among major Leishmania groups. 
with the separation of Gondwana in the Mesozoic; Paraleishmania with the introduction of hystricomorph rodents in the early Cenozoic; $L$. mexicana with the formation of the Panamanian land bridge in the Pliocene and $L$. chagasi in Recent.

\section{REFERENCES}

Ashford RW 1986. Speculations on the origins and evolution of Old World Leishmania system. In JA Rioux, Leishmania, Taxonomie et Phylogenèse. Application Éco-epidemiologiques (Colloque International du CNRS/INSERM, 1984), IMEE, Montpellier, p. 257264.

Ashford RW, Seaman J, Schorscher J, Pratlong F 1992. Epidemic visceral leishmaniasis in the Sudan: identity and systematic position of the parasites from patients and vectors. Trans R Soc Trop Med Hyg 86: 379-380.

Croan DG, Morrison DA, Ellis JT 1997. Evolution of the genus Leishmania revealed by comparison of DNA and RNA polymerase gene sequences. Mol Biochem Parasitol 89: 149-159.

Cupolillo E, Grimaldi Jr G, Momen H, Beverley SM 1995. Intergenic region typing (IRT): a rapid molecular approach to the characterization and evolution of Leishmania. Mol Biochem Parasitol 73: 145155.

Cox CB, Moore PD 2000. Biogeography an Ecological and Evolutionary Approach, 6th ed., Blackwell Science, Oxford, 298 pp.

Cupolillo E, Medina-Acosta E, Noyes H, Momen H, Grimaldi Jr G 2000. A revised classification for Leishmania and Endotrypanum. Parasitol Today 16: 142144.

Cruz F, Davies J 2000 Horizontal gene transfer and the origin of species. Trend Ecol Evol 8: 128-133.

Doolittle WF 1999. Phylogenetic classification and the Universal Tree. Science 284: 2124-2128.

Felsenstein J 1988. Phylogenies from molecular sequences: inference and reliability. Annu Rev Genet 22: 521-565.

Kerr SF 2000. Paleartic origin of Leishmania. Mem Inst Oswaldo Cruz 95: 75-80.

Killick-Kendrick R, Molyneux DH, Rioux JA, Lanotte G 1980. Possible origins of Leishmania chagasi. Ann Trop Med Parasitol 74: 563-565.

Killick-Kendrick R, Lainson R, Rioux JA, Saf'janova VM 1986. The taxonomy of Leishmania-like parasites of reptiles. In JA Rioux, Leishmania, Taxonomie et Phylogenèse. Application Éco-epidemiologiques (Colloque International du CNRS/INSERM, 1984), IMEE, Montpellier.

Lainson R, Shaw JJ 1987. Evolution, classification and geographical distribution. In W Peters, R KillickKendrick (eds), The Leishmaniasis in Biology and Epidemiology, Vol. 1, Academic Press, London, p. 1120.

Lanotte G, Rioux JA, Serres E 1986. Approche cladistique du genre Leishmania, Ross, 1903. A propos de 192 souche originaires de l'Ancien Monde. Analyse numerique de 50 zymodèmes identifiés par 15 enzymes et 96 isoenzymes. In JA Rioux Leish- mania, Taxonomie et Phylogenèse. Application Écoepidemiologiques (Colloque International du CNRS/ INSERM, 1984), IMEE, Montpellier, p. 269-288.

Lawrence JG, Ochman H 1998. Molecular archaeology of the Echerichia coli genome. Proc Nat Acad Sci USA 95: 9413-9417.

Lysenko AJ 1971. Distribution of leishmaniasis in the Old World. Bull WHO 44: 515-520.

Mauricio IL, Howard MK, Stothard JR, Miles MA 1999. Genomic diversity in the Leishmania donovani complex. Parasitology 119: 1-10.

McMahon-Pratt D, Traub-Cseko Y, Lohman KL, Rogers DD, Beverley SM 1992. Loss of the GP46/M-2 surface membrane glycoprotein gene family in the Leishmania braziliensis complex. Mol Biochem Parasitol 50: 151-160

Mebratu YB, Lawyer PG, Ngumbi PM, Karigi G, Mbugua J, Gachihi G, Wasuna K, Pamba H, Sherwood JA, Koech DK, Poberts CR 1992. A new rural focus of cutaneous leishmaniasis caused by Leishmania tropica in Kenya. Trans $R$ Soc Trop Med Hyg 86: 381-387.

Momen H, Grimaldi Jr G, Dean LM 1987. Leishmania infantum, the aetiological agent of American visceral leishmaniasis (AVL)? Mem Inst Oswaldo Cruz 82: 447-448.

Moreno G, Rioux JA, Lanotte G, Pratlong F, Serres E 1986. Le complexe Leishmania donovani s.l. analyse enzymatique et traitement numerique. Individualization du complexe Leishmania infantum. Corollaires biogeographiques et phyletiques. A propos de 146 souches originaires de l'Áncien et du Noveau Monde. In JA Rioux, Leishmania, Taxonomie et Phylogenèse. Application Éco-epidemiologiques (Colloque International du CNRS/INSERM, 1984), IMEE, Montpellier, p. 105-107.

Noyes HA 1998. Implications of a neotropical origin of the genus Leishmania. Mem Inst Oswaldo Cruz 93: 657-661.

Noyes HA, Chance ML, Croan DG, Ellis JT 1998. Leishmania (Sauroleishmania): a comment on classification. Parasitol Today 14: 167.

Okot-Kotber BM, Mutinga MJ, Kiddu JB 1989. Biochemical characterization of Leishmania spp. Isolated from man and wild animals in Kenya. Int $J$ Parasitol 19: 657-663.

Pacheco RS, Thomaz N, Momen H 1990. kDNA crosshybridization between Endotrypanum and peripylarian Leishmania. Trans $R$ Soc Trop Med Hyg 84: 531

Phillipe H 1998. Molecular phylogeny of kinetoplasts. In GH Coomb, K Vickerman, MA Sleigh, A Warren (eds), Evolutionary Relationships among Protozoa, Systematics Association, London, p. 195-212.

Rioux JA, Lanottte G, Pratlong F 1986. Leishmania killicki n. sp. (Kinetoplastida, Trypanosomatidae). In JA Rioux, Leishmania, Taxonomie et Phylogenèse. Application Éco-epidemiologiques (Colloque International du CNRS/INSERM, 1984), IMEE, Montpellier, p. 139-142.

Saf'janova VM 1986. The problems of the classification and phylogeny of the Leishmania. In JA Rioux, Leishmania, Taxonomie et Phylogenèse. Application 
588 Major Divisions in the Genus Leishmania - H Momen, E Cupolillo

Éco-epidemiologiques (Colloque International du CNRS/INSERM, 1984), IMEE, Montpellier, p. 247255.

Sang DK, Njeru WK, Ashford RW 1994. A zoonotic focus of cutaneous leishmaniasis due to Leishmania tropica at Utut, Rift Valley Province, Kenya. Trans $R$ Soc Trop Med Hyg 88: 35-37.

Stothard JR 2000. Trypanosome trees and homologies. Parasitol Today 16: 173.
Telford Jr SR 1995. The kinetoplastid hemoflagellates of reptiles. In JP Kreier, Parasitic Protozoa, Vol. 10, Academic Press, London, p. 161-223.

Thomaz-Soccol V, Lanotte G, Rioux JA, Pratlong F, Martini-Dumas A, Serres E 1993. Monophyletic origin of the genus Leishmania Ross, 1903. Ann Parasitol Hum Comp 68: 107-108.

Yang Z 1996. Among site rate variation and its impact on phylogenetic analysis. Trend Ecol Evol 11: 367-372. 